\title{
PENETRASI PENDIDIKAN ISLAM PADA BUDAYA DAN AGAMA MASYARAKAT
}

\author{
Oleh: A. Thoyib Mas'udi \\ Program Doktor Pascasarjana UNISMA Malang \\ Email : thoyyib61@yahoo.com
}

\begin{abstract}
Abstrak
Proses penetrasi pendidikan Islam pada budaya dan agama masyarakat di desa Pulopancikan Gresik bersifat akulturatif dengan corak overt culture melalui beberapa unsur budaya masyarakat yang meliputi: sistem religi dan upacara keagamaan, sistem kekerabatan dan organisasi sosial, sistem teknologi dan sistem bahasa. Selain melalui unsur budaya masyarakat, penetrasi akulturatif juga dijalankan melalui sistem agama masyarakat yang meliputi: haddad-an, majelis rawhah, haul Habib Abu Bakar bin Muhammad Assegaf, perayaan tahun baru Imlek, dan sembahyang saling berebut.
\end{abstract}

Kata kunci: Penetrasi Sosial, Pendidikan Islam.

\section{Abstract}

The process of penetration of Islamic education in the culture and religion of the community in Pulopancikan Gresik village is acculturative with a pattern of overt culture through several elements of community culture which include: religious systems and religious ceremonies, kinship systems and social organizations, technological systems and language systems. In addition through cultural elements of society, acculturative penetration is also carried out through the community's religious system which includes: haddad-an, rawhah assembly, haul Habib Abu Bakar bin Muhammad Assegaf, Chinese New Year celebrations, and scrambling prayers.

Keywords: social penetration, islamic education

\section{PENDAHULUAN}

Desa Pulopancikan merupakan salah satu desa di Kabupaten Gresik yang pernduduknya bersifat multikultur yang multi etnis dan multi agama. Penduduk desa ini terdiri dari beragam etnis, antara lain: etnis Jawa, etnis Madura, etnis Sulawesi, etnis Tionghoa, dan etnis Arab. Perbedaan etnis di atas, membawa perkembangan pada ragam agama di desa Pulopancikan ini dimana terdapat sekitar lima varian agama di Pulopancikan Gresik, antara lain: Islam, Katolik, Protestan, Budha dan Konghuchu. Disamping itu, keberagaman etnis juga turut membawa pada varian-varian kebudayaan di desa Pulopancikan Gresik. 
Meski berbeda etnis, agama, dan budaya, namun keharmonisan dan kerukunan antar etnis dan umat beragama ini dapat terwujud, salah satunya adalah karena keberadaan sejumlah lembaga pendidikan yang telah mengikat hubungan antar etnis dan umat beragama melalui proses penetrasi sosial sehingga keadaan masyarakat dapat menjadi harmonis. Beberapa lembaga pendidikan tersebut adalah SD Setia Budi Bedilan Gresik. Sekolah ini merupakan sekolah yang sebagian besar menjadi tempat belajar bagi anak-anak desa Pulopancikan yang dihuni oleh sejumlah peserta didik dari Pulopancikan yang memiliki latar belakang Etnis Tionghoa dan Jawa, serta agama Islam, Protestan, Budha, Konghuchu dan Katolik.

Sekolah lainnya adalah SMP Darul Islam. Remaja desa Pulopancikan yang memiliki latar belakang etnis Jawa dan Arab lebih banyak belajar di sekolah ini. Sebab sekolah ini merupakan satu-satunya sekolah tingkat SLTP berbasis Islam yang terdekat dengan desa Pulopancikan Gresik. Muslim Jawa dan Arab lebih banyak belajar di sekolah ini dengan tujuan selain mendalami ilmu umum, sekaligus juga mendalami ilmu agama Islam. SMP Darul Islam juga mengajarkan tentang pentingnya sikap saling menghargai antar sesama dalam pembelajara. Sekolah ini menyadari keberadaan lembaganya berada ditengah-ragam etnis dan agama yang berbeda.

Di sisi lain, pendidikan Islam pada lingkungan masyarakat juga turut memberikan sumbangan penting dapat pembentukan kerukunan dan keharmonisan masyarakat desa Pulopancikan. Pendidikan islam tersebut pada umumnya banyak dilakukan melalui kegiatan-kegiatan yang berupa tahlilan, yasinan, hadad-an, dan haul. Melalui kegiatan tersebut seringkali dimasuki acara ceramah agama yang materinya lebih banyak memuat tentang pentingnya sikap saling menghargai, toleransi, persaudaraan, kerukunan, dan semacamnya. Penyelenggara kegiatan pada umumnya telah menyadari kemajemukan masyarakat desa Pulopancikan yang terdiri dari berbagai etnis, agama dan budaya.

Pertanyaan yang penting untuk diajukan kemudian adalah, bagaimana proses terbentuknya masyarakat multikultural di Pulopancikan ini?. Jika ditelusuri, maka jawaban sementara yang dapat diajukan adalah bahwa terbentuknya masyarakat multikultural di desa Pulopancikan Gresik disebabkan karena faktor peran pendidikan Islam dalam melakukan penetrasi budaya dan agama.

Dalam penelusuran kajian se-tema kajian yang telah dilakukan oleh para ahli, penulis menemukan sejumlah penelitian yang se-tema dari sisi pandangan tentang relasi agama dengan budaya yang memiliki persamaan dan perbedaan dengan kajian penulis. Kajian tersebut menunjukkan adanya tipologi kajian agama dalam konteks budaya lokal yang dapat dikategorikan 
menjadi tiga tipologi. Pertama, hubungan agama dengan budaya lokal yang bercorak sinkretik (asimilasi) seperti kajian Greetz (1981), Manan (1999), Masyhudi (1999), Edwin Fiantiano dkk. (1998), Huesin S. Ali (1990), Raymond Firth (1990), Andrew Beatty (1996), Hutomo (2011), dan Neils Mulder (1999). Kedua, hubungan agama dengan budaya lokal yang secara gamblang bercorak akulturatif seperti kajian Hefner (1985), Woodward (1989), Muhaimin (2001), Budiwanti (2000), Hilmy (2001), Hendro Prasetyo (1993), Headley (1997), ${ }^{1}$ Abdullah (1989), Mukti Ali (1980), Nakamura (1983), Mulkan (2000), ${ }^{2}$ Radam (2001), dan Bartholomew (2001). ${ }^{3}$ Ketiga, hubungan agama dengan budaya lokal yang bercorak kolaboratif (akulturasi-sinkretik) seperti kajian Nur Syam (2005). Ketiga tipologi tersebut kiranya belum menunjukkan gambaran yang jelas tentang dialektika agama dan budaya dalam setting masyarakat multikultural. Sebab kajian yang dilakukan oleh para ahli kebanyakan dilakukan dalam setting pedalaman.

Di sisi lain, penulis juga menemukan sejumlah penelitian yang setema dari sisi model interaksi masyarakat dalam setting masyarakat multikultur yang memiliki persamaan dan perbedaan dengan kajian penulis. Kajian tersebut menunjukkan bahwa kajian tentang sejumlah model interaksi masyarakat multikultur dapat dipetakan menjadi dua tipologi. Pertama, interaksi masyarakat multikultur melalui proses akulturasi dan asimilasi secara sekaligus seperti penelitian yang dilakukan oleh Muhammad Arif (2014). Kedua, interaksi masyarakat multikultur melalui proses sinkretik (asimilasi) seperti penelitian yang dilakukan oleh Anita Sugianta dkk. (2014), Mahruddin (2013) dan Sehat Ihsan Shadiqin (2011). Kecenderungan diatas akan dikaji dalam penelitian ini dengan setting masyarakat multikultur. Harapannya penulis dapat menemukan corak dialektika agama dan budaya, apakah sinkretik (asimilasi), akulturasi ataukah bercorak kolaboratif (akulturasi-sinkretik). Dari penjelasan pada konteks penelitian di atas, maka selanjutnya penelitian ini akan difokuskan untuk mengkaji dan menganalisis bagaimana proses penetrasi pendidikan Islam pada budaya dan agama masyarakat di desa Pulopancikan Gresik.

\footnotetext{
${ }^{1}$ Stephen Headly, The Islamization of Central Java; The Role of Muslim Lineage in Kalioso. Jurnal: Volume 3 Nomor 2. Islamika, 1997.

2 Abdul Munir Mulkhan, Islam Murni Pada Masyarakat Petani. (Yogyakarta; Bentang Budaya, 2000).

3 John Ryan Bartholomew. Alif Lam Mim; Kearifan Masyarakat Sasak. (Yogyakarta; Tiara Wacana, 2001).
} 


\section{METODE}

Dalam penelitian ini menggunakan pendekatan penelitian kualitatif dengan jenis penelitian etnografis. Penelitian ini dilakukan di desa Pulopancikan Kecamatan Gresik Kabupaten Gresik. Dalam menentukan informan, penelitian ini menggunakan teknik purposive sampling dan snowball sampling. Adapun teknik pengumpulan data dalam penelitian ini menggunakan teknik observasi partisipatif (participan observation), wawancara mendalam (in depth interiview) dan dokumentasi (document review). Pada proses analisis data, penulis meminjam model analisis etnografi yang dirumuskan oleh Spreadley. Adapun untuk melakukan audit hasil penelitian, penelitian ini dilakukan dengan perpanjangan pengamatan, peningkatkan ketekuman, dan triangulasi.

\section{PEMBAHASAN}

Dalam penjelasan Altman \& Taylor bahwa penetrasi sosial terjadi dalam empat tahap, yaitu: tahap orientasi, penjajakan pertukaran afektif, pertukaran afektif, dan pertukaran stabil. ${ }^{4}$ Penetrasi pendidikan islam pada budaya dan agama masyarakat Pulopancikan terjadi secara bertahap sebagaimana rumusan Altman \& Talylor. Namun jika diklasifikasikan hubungan masyarakat lokal dengan kelompok etnis lainnya ternyata ada perbedaan. Hubungan masyarakat lokal dengan kelompok etnis Arab berakhir sampai pada tahap penjajakan pertukaran afektif. Sementara hubungan masyarakat lokal dengan kelompok Etnis Tionghoa berakhir sampai pada tahap pertukaran stabil. Pada tahap orientasi, masyarakat muslim, terutama etnis lokal memulai membuka diri secara sedikit demi sedikit kepada komunitas lain. Proses orientasi dilakukan melalui interaksi masyarakat etnis lokal dengan komunitas etnis lainnya pada tingkat publik. Interaksi dengan komunitas etnis Tionghoa misalnya, masyarakat lokal membuka diri dengan meramaikan Klenteng Kim Hin Kiong, baik dalam kesehariannya maupun ketika ada upacara ritual-ritual keagamaan. Biasanya beberapa individu etnis lokal hanya sekadar dolan (bermain-main) di Klenteng tersebut, bahkan hanya berbincang-bincang. Lebih dari itu, setiap ada upacara ritual keagamaan di Klenteng Kim Hin Kiong masyarakat lokal selalu hadir.

Mereka itu juga menyadari bahwa keberadaan Klenteng berimplikasi pada keberadaan komunitas agama Konghuchu dan Budha sebagai realitas sejarah dan bagian dari identitas mereka juga. Menjaga peninggalan sejarah dan budaya merupakan bagian dari tugas masyarakat. Untuk itu, masyarakat lokal mensosialisasikan konsep demokrasi, penghargaan, dan pengakuan

${ }^{4}$ Richard West \& Lynn H. Turner. Introducing Communication Theory: Analysis and Aplication. (New York: Mc Graw-Hill Higher Education, 2007), 205-208. 
terhadap perbedaan melalui berbagai kegiatan pendidikan Islam, baik melalui lingkungan pendidikan formal seperti sekolah, atau madrasah maupun lingkungan masyarakat dalam kegiatan-kegiatan keagamaan seperti, tahlil, yasinan, dan, peringatan maulid ar rasul, dan sebagainya. Sementara itu, terhadap komunitas etnis arab, masyarakat lokal juga membuka diri dengan mengikuti berbagai ritual keagamaan islam yang dijalankan oleh komunitas arab, seperti haddad-an, majelis rawhah, haul Habib Abu Bakar bin Muhammad Assegaf.

Dari keterlibatan komunitas lokal dengan komunitas etnis Tionghoa dan Arab membuat komunikasi antar etnis mulai terjalin, meski belum sampai pada komunikasi yang bersifat impersonal. Sebab para individu yang terlibat dalam komunikasi hanya menyampaikan informasi bersifat sangat umum saja. Oleh karena itu, hanya sebagian kecil informasi tentang identitas masing-masing komunitas yang terungkap, terutama informasiinformasi yang bersifat umum atau informasi simbolik yang hanya bisa ditangkap oleh mata, seperti: pakaian, gaya bicara, logat, sikap, dan sebagainya. Dalam tahap orientasi ini, individu-individu etnis lokal lebih bersikap hati-hati agar tidak mengganggu kepentingan dan hal-hal privat komunitas etnis lain. Apalagi mengevaluasi atau mengkritik komunitas etnis lain.

Kalaupun ada evaluasi atau kritik, biasanya hanya dipendam dalam hati sebagai informasi pribadi individu saja. Salah satu kritik masyarakat terhadap kelompok etnis arab adalah sikap mereka yang kurang terbuka dengan komunitas etnis lainnya karena kurang membaur dan mereka jarang keluar rumah untuk berinteraksi dengan tetangga maupun orang lain diluar etnis mereka. Sebagian besar etnis Arab dianggap oleh orang-orang lokal hanya lebih mementingkan urusan perdagangan mereka, sehingga dianggap tidak punya waktu untuk berinteraksi dengan tetangga ataupun masyarakat sekitar. Meskipun yang dirasakan orang-orang lokal seperti itu, namun mereka berusaha secara aktif untuk menghindarkan diri agar tidak terlibat dalam konflik. Masyarakat etnis lokal menyadari bahwa etnis Arab maupun Etnis Tionghoa merupakan kelompok masyarakat minoritas yang posisi mereka di dalam masyarakat tidak begitu dominan. Namun masyarakat lokal menyadari bahwa kemajemukan etnis dan agama di desa Pulopancikan adalah realitas sosial yang tidak terbantahkan. Lebih dari itu, adanya kemajemukan etnis dan agama di desa pulopancikan Gresik adalah realitas sejarah Gresik yang lestari hingga kini.

Dari gambaran di atas menunjukkan bahwa informasi yang terbuka dari kedua pihak adalah informasi mengenai citra publik pada masingmasing kelompok etnis, baik kelompok Etnis Tionghoa, Arab, maupun masyarakat lokal. Berkaitan dengan hal ini jika dianalogikan sebagaimana 
teori bawang, maka hal ini merupakan informasi lapisan terluar. Tahapan proses pembentukan hubungan di atas diumpamakan seperti proses menembus kedalaman bawang yang berlapis-lapis. Bawang ini memiliki sejumlah lapisan yang semakin terbuka kulit terluar maka informasi yang diperoleh akan semakin kedalam. Lapisan terluar dalam analogi ini ialah citra publik (public image) seorang individu yang dapat dilihat dan dirasakan secara langsung. Dalam lapisan terluar ini masyarakat lokal telah memperoleh informasi tentang lapisan terluar dari kelompok Etnis Tionghoa dan kelompok etnis Arab. Dan sebaliknya, kelompok etnis Arab maupun kelompok Etnis Tionghoa telah memperoleh informasi mengenai lapisan terluar dari masyarakat lokal yang dapat ditangkap secara kasat mata.

Adapun pada tahap pertukaran penjajakan aktif, masyarakat muslim Pulopancikan diri mereka sudah mulai muncul, dan begitu pula dengan komunitas Etnis Tionghoa dan arab juga sudah mulai muncul. Altman \& Taylor menjelaskan bahwa pada tahap penjajakan afektif ini ditandai dengan munculnya diri yang dicirikan dengan apa yang tadinya pribadi mulai menjadi publik. ${ }^{5}$

Pada tahap itu komunitas arab, komunitas cina dan masyarakat lokal sudah mulai memunculkan kepribadian mereka. Hal ini terbukti dari adanya sikap dan pengakuan akan keberadaan Klenteng Kim Hin Kiong sebagai bagian dari identitas mereka. Tidak jarang masyarakat lokal berpartisipasi dalam bersih-bersih klenteng, terlibat dalam persiapan uapacara Imlek, menghadiri hiburan Barongsai, wayang potehi, dan wayang thithi. Bahkan beberapa orang dari luar desa Pulopancikan terlibat memperjuangkan Klenteng Kim Hin Kiong untuk di daftarkan sebagai sisa-sisa peninggalan sejarah ke Balai Pelestarian dan Peninggalan Purbakala (BP3) Jawa Timur. Lebih dari itu, beberapa diantara pegawai dan pengurus klenteng Kim Hin Kiong adalah orang-orang dari masyarakat lokal. Pada tahap ini pola komunikasi masyarakat lokal, komunitas etnis Arab, dan Etnis Tionghoa sudah mulai menggunakan bahasa lokal (bahasa jawa) meskipun kadangkadang campur dengan bahasa Indonesia. Di antara mereka sudah mulai berbincang-bincang antar individu yang bersifat personal meskipun belum mendalam sampai pada hal-hal yang bersifat intim. penulis melihat percakapan yang bersifat personal sering kali terjadi dalam pertemuan di rumah toko miliki etnis Tionghoa, baik ketika berbelanja atau sekadar berbincang-bincang. Selain itu, percakapan impersonal antara individu etnis lokal dengan individu etnis Tionghoa juga terjadi ketika ada kegiatan bersih-bersih desa. Penulis mengamati bahwa aktivitas percakapan antara etnis lokal dengan Etnis Tionghoa jauh lebih lepas dibanding dengan etnis 


\section{PENDIDIKAN MULTIKULTURAL}

arab. Beberapa kali terlihat mereka yang sedang bercakap-cakap tertawa lepas meskipun penulis tidak begitu tahu apa yang sedang diperbincangkan. Penulis melihat sepertinya tidak ada sikap kehati-hatian dalam berbicara diantara keduanya.

Interaksi interpersonal yang terjadi antara masyarakat lokal dengan komunitas etnis arab berada dalam bingkai tersembunyi sebagaimana gambaran teori Johari Window. Dalam teori ini dijelaskan bahwa jendela terbagi atas empat bingkai. Pada bingkai pertama disebut dengan bidang terbuka. Pada bidang ini menunjukkan orang yang terbuka kepada orang lain yang terjadi karena dua pihak (saya dan orang lain) sama-sama mengetahui informasi, perilaku, sikap, perasaan, keinginan, motivasi, gagasan, dan lain-lain. Bidang ini merupakan bidang yang ideal untuk komunikasi interpersonal. Pada bingkai kedua disebut dengan bidang buta. Bidang ini menjelaskan bahwa orang yang tidak mengetahui dirinya sendiri tetapi orang lain banyak tahu tentang dirinya. Pada bingkai ketiga disebut bidang tersembunyi. Pada bidang ini seseorang menyembunyikan banyak hal tentang dirinya dan tidak ada orang lain yang mengetahuinya. Sedangkan bingkai keempat disebut bidang tidak dikenal.

Berbeda dengan hubungan masyarakat lokal dengan Komunitas etnis Arab, hubungan antara masyarakat lokal dengan komunitas Etnis Tionghoa berlanjut pada tahap ketiga, yaitu tahap pertukaran afektif. Hal ini disebabkan karena keterbukaan dan keakraban antara masyarakat lokal dengan komunitas Etnis Tionghoa telah terbentuk. Keterbukaan telah terbangun dengan adanya perlibatan orang-orang lokal desa Pulopancikan Gresik sebagai pegawai atau tenaga kerja di rumah toko yang dikelola oleh orang-orang Etnis Tionghoa. Selain itu, orang-orang Etnis Tionghoa juga melibatkan sejumlah warga lokal sebagai tenaga kebersihan di Klenteng Kim Hin Kiong. Bahkan terdapat beberapa orang warga lokal yang dilibatkan sebagai pengurus Klenteng Kim Hin Kiong. Di samping itu, dalam keseharian orang-orang Etnis Tionghoa sering berinteraksi dengan masyarakat lokal. Mereka sering ngobrol di pinggir jalan atau di depan rumah mereka yang kebetulan tak berteras. Keterbukaan dan keakraban tersebut juga terbukti dengan keikutsertaan orang-orang Etnis Tionghoa dalam kegiatan bersih-bersih desa dalam rangka menyambut peringatan hari kemerdekaan RI. Lebih dari itu, mereka ikut serta dalam beberapa perlombaan Agustusan yang diselenggarakan oleh masyarakat lokal, yakni lomba tenis meja yang beberapa diantara mereka sering kali juara. Selain itu, adanya pernikahan antara Etnis Tionghoa dengan etnis lokal membuat hubungan antar komunitas etnis dapat lebih mencair.

Jika dilihat dari teori self of disclosure model Johari Window menunjukkan bahwa hubungan antara masyarakat lokal dengan komunitas 
Etnis Tionghoa berada pada bingkai terbuka. Dalam teori ini menjelaskan bahwa dalam bingkai terbuka menunjukkan orang yang terbuka kepada orang lain. Keterbukaan ini terjadi karena dua pihak (saya dan orang lain) sama-sama mengetahui informasi, perilaku, sikap, perasaan, keinginan, motivasi, gagasan, dan lain-lain. Secara teoritik bidang ini merupakan bidang yang ideal untuk komunikasi interpersonal. Masyarakat etnis Tionghoa sudah terbuka dengan masyarakat lokal. Oleh karena itu, kedua kelompok etnis tersebut telah sama-sama mengetahui dan memahami perilaku, sikap, perasaan, motivasi, gagasan, pandangan hidup dan sebagainya. Oleh sebab itu, keterbukaan inilah yang menjadi sarana bagi hubungan masyarakat lokal dengan kelompok etnis Tionghoa ke tahap berikutnya, yaitu pertukaran afektif.

Pada tahap pertukaran afektif, Altman \& Taylor menjelaskan bahwa pada tahap ketiga ini ditandai dengan komitmen dan kenyamanan yang dicirikan oleh dengan proses komunikasi yang sering kali berjalan spontan dan individu membuat keputusan yang cepat, sering kali dengan sedikit memberikan perhatian untuk hubungan secara keseluruhan. Munculnya hubungan persahabatan yang dekat atau hubungan antara individu yang lebih intim. Munculnya perasaan kritis dan evaluatif pada level yang lebih dalam. ${ }^{6}$.

Pada tahap itu masyarakat lokal maupun kelompok etnis Tionghoa masing-masing memiliki komitmen dan kenyamanan dalam hubungan sosial diantara keduanya. Karena itu, pola komunikasi yang terjadi antara individu yang berasal dari kedua etnis tersebut terlihat sangat cair. Dan responrespon yang keluar dari komunikasi keduanya terlihat spontan dan tanpa dibuat-buat. Dalam interaksinya, hampir setiap hari masing-masing individu bertemu dan berbincang-bincang mengenai berbagai perihal.

Lebih dari itu, perbincangan di antara mereka sudah mlai masuk pada aspek-aspek yang lebih intim. Bahkan beberapa di antara masyarakat lokal diberikan kewenangan untuk mengatur dan mengurus Klenteng Kim Hin Kiong. Orang-orang Etnis Tionghoa yang percaya dan komitmen dengan masyarakat lokal bahwa mereka perduli dengan eksistensi dan masa depan mereka. Oleh karena itu, masyarakat lokal dapat biasa memberikan saran, masukan, nasihat, bahkan evaluasi kepada orang-orang Tionghoa. Sebaliknya, kelompok Etnis Tionghoa dapat menerima saran, masukan, nasihat, dan evaluasi dari masyarakat lokal. Altman \& Taylor menjelaskan bahwa adanya perilaku saling kritik, perbedaan pendapat dan bahkan permusuhan antar individu, semua itu menurut Altman \& Taylor, belum berpotensi mampu mengancam kelangsungan hubungan yang sudah terbina.

${ }^{6}$ Ibid, 


\section{PENDIDIKAN MULTIKULTURAL}

Pada tahap pertukaran afektif ini lapisan keluasan (breadth) telah terbuka. Menurut Altman \& Taylor, lapisan keluasan adalah sesuatu yang merujuk pada berbagai tema yang didiskusikan dalam suatu hubungan. Keluasan ini berhubungan dengan waktu yang mengandung arti jumlah waktu yang digunakan dalam suatu hubungan komunikasi antara satu individu dengan individu lainnya tentang tema yang sedang didiskusikan. Altman \& Taylor membedakan keluasan ini menjadi dua bagian, yaitu: pertama, kategori keluasan (breadth category), yaitu keluasan yang mengarah pada wilayah umum dari masing-masing kepribadian dimana keduanya memiliki sejumlah bagian-bagian yang spesifik, seperti: jenis kelamin, agama, keluarga, minat, hobi dan sebagainya. Kedua, frekuensi keluasan (breadth frequency), yaitu keluasan yang mengarah pada sebuah anggapan bahwa setiap wilayah kepribadian memiliki materi yang spresifik atau potongan-potongan data. ${ }^{7}$

Pada tahap pertukaran afektif ini, masyarakat lokal maupun kelompok Etnis Tionghoa dapat saling berbagi emosi, perasaan, keyakinan agama, sudut pandang. Masing-masing mengetahui wilayah kepribadian sekaligus standar kepribadiannya. Karena pengetahuan itulah, masingmasing kelompok sudah dapat memperkirakan akibat atas sikap dan perilakunya kepada kelompok lain. Karena pengetahuan itulah, kelompok etnis Tionghoa misalnya, dalam perbincangan dengan etnis lokal biasanya dihentikan ketika terdengar suara adzan dalam rangka menghormati kelompok muslim lokal. Dan sebaliknya, masyarakat lokal menghormati dan mentoleransi kebiasaan kelompok Etnis Tionghoa yang suka memlihara anjing dan suka mengkonsumsi daging babi. Masyarakat lokal telah mengetahui bahwa daging babi sangat bermakna bagi kelompok Etnis Tionghoa yang melambangkan bumi dalam pandangan ajaran tri dharma. Altman \& Taylor melanjutkan bahwa pada umumnya tahap ketiga ini tidak akan dimasuki, kecuali para pihak pada tahap sebelumnya telah menerima imbalan yang cukup berarti dibandingkan dengan biaya yang dikeluarkan. ${ }^{8}$.

Keberlanjutan hubungan pada tahap pertukaran afektif antara kelompok etnis Tionghoa dengan masyarakat lokal ditentukan adanya pertukaran antara imbalan (reward) yang diterima dan biaya (cost) yang dikeluarkan oleh masing-masing kelompok. Masyarakat etnis Tionghoa membutuhkan imbalan berupa penghargaan dan pengakuan atas eksistensi etnis, agama, budaya, dan identitas sosial mereka sebagai masyarakat Indonesia. Untuk memperoleh imbalan itu, cost yang mereka berikan kepada masyarakat lokal berupa membuka diri kepada masyarakat lokal, menghormati agama mereka, menghormati budaya mereka, dan

\footnotetext{
${ }^{7}$ Ibid. 200-202

${ }^{8}$ Ibid.
} 
menghormati kelas sosial mereka. Salah satu bentuk bukti penghargaan kelompok etnis Tionghoa kepada masyarakat lokal adalah saat mereka melakukan kegiatan acara ramai-ramai atau perayaan di klenteng yang dilakukan pada siang hari, seketika itu juga terdengar suara qiroah atau bedug yang terdengar dari masjid yang merupakan tanda waktu sholat bagi umat Islam, maka kegiatan di klenteng pun berhenti sejenak, baru setelah adzan selesai mereka melanjutkannya kembali.

Bukti lainnya adalah kebiasaan etnik Tionghoa dalam mengkonsumsi daging babi. Kelompok etnik ini pada umumnya sangat suka mengkonsumsi daging babi. Meski demikian, mereka biasanya enggan untuk menyembelih babi sendiri dirumah mereka. Alasannya adalah untuk menghormati warga lain yang mengharamkan untuk mengkonsumsi daging babi. Alternatifnya kelompok etnis Tionghoa biasanya membeli daging babi ke Surabaya untuk dimasak dan dikonsumsi di rumahnya masing-masing. Sama halnya dengan warga muslim di desa Pulopancikan juga berusaha untuk menghormati kebiasaan kelompok etnis Tionghoa yang lebih suka mengkonsumsi daging babi. Adapun reward yang diperlukan oleh masyarakat lokal adalah terjaganya stabilitas sosial di desa Pulopancikan. Sementara cost yang diberikan oleh masyarakat lokal adalah pemberian rasa penghargaan dan pengakuan atas keberadaan kelompok etnis lokal serta melindungi identitas sosial mereka. Hal itu diwujudkan melalui pemberian ruang kebebasan bagi kelompok Etnis Tionghoa untuk mengekspresikan keagamaan, tradisi, dan identitas sosial mereka. Hal ini terbukti dari adanya sikap toleransi mereka pada kebiasaan kelompok Etnis Tionghoa yang sebagian dari mereka suka memelihara anjing dirumahnya. Mereka juga mentoleransi dan menghargai kebiasaan kelompok Etnis Tionghoa yang dikenal hobi mengkonsumsi daging babi. Begitu pula dalam hal ekspresi keagamaan, masyarakat lokal menghargai, dan mentoleransi, bahkan berpartisipasi dalam upacara ritual keagamaan mereka seperti perayaan ritual tahun baru Imlek, ritual hari Cap Go Meh, dan sebagainya.

Dari gambaran di atas mempertegas asumsi dasar teori penetrasi sosial bahwa: Pertama, hubungan-hubungan mengalami kemajuan dari tidak intim menjadi intim. Hubungan komunikasi antara orang dimulai pada tahapan superficial dan bergerak pada sebuah kontinium menuju tahapan yang lebih intim. Kedua, secara umum, perkembangan hubungan sistematis dan dapat diprediksi. Hubungan seperti proses komunikasi bersifat dinamis dan terus berubah, tetapi bahkan sebuah hubungan yang dinamis mengikuti standar dan pola perkembangan yang dapat diterima. Ketiga, perkembangan hubungan mencakup depenetrasi (penarikan diri) dan disolusi. Jika sebuah hubungan mengalami depenetrasi, hal itu tidak berarti bahwa hubungan itu akan secara otomatis hilang atau berakhir. Sering kali, suatu hubungan akan 


\section{PENDIDIKAN MULTIKULTURAL}

mengalami transgresi atau pelanggaran aturan, pelaksanaan dan harapan dalam berhubungan. Bila suatu hubungan menjadi rusak, keluasan dan kedalaman sering kali akan (tetapi tidak selalu) menurun. Keempat, Pembukaan diri adalah inti dari perkembangan hubungan. Pembukaan diri (self-disclosure) dapat secara umum didefinisikan sebagai proses pembukaan informasi mengenai diri sendiri kepada orang lain yang memiliki tujuan. Hubungan yang tidak intim bergerak menuju hubungan yang intim karena adanya keterbukaan diri. Proses ini memungkinkan orang untuk saling mengenal dalam sebuah hubungan. Pembukaan diri membantu membentuk hubungan masa kini dan masa depan dan membuat diri terbuka terhadap orang lain memberikan kepuasan yang intrinsik. ${ }^{9}$

Dengan demikian, berdasarkan deskripsi panjang yang telah diuraikan di atas dapat disimpulkan bahwa proses penetrasi pendidikan islam pada budaya dan agama masyarakat desa Pulopancikan Gresik adalah bersifat akulturatif. Menurut Koentjaraningrat, akulturasi adalah proses perpaduan antara dua kebudayaan atau lebih sehingga melahirkan bentuk kebudayaan baru, tetapi unsur-unsur penting dari masing-masing kebudayaan (baik kebudayaan lama maupun kebudayaan baru) masih bertahan. Akulturasi ini terjadi bila suatu kelompok manusia dengan suatu kebudayaan tertentu dihadapkan dengan unsur-unsur dari suatu kebudayaan asing, sehingga unsur-unsur kebudayaan asing itu lambat laun diterima dan diolah ke dalam kebudayaan sendiri tanpa menyebabkan hilangnya kepribadian kebudayaan itu sendiri. ${ }^{10}$

Model akulturasi yang ada di desa Pulopancikan Gresik terbukti dengan keberadaan sejumlah simbol budaya lokal yang masuk pada budaya masyarakat seperti: lontong cap go meh, dan pertunjukan wayang kulit dalam perayaan tahun baru imlek, serta arak-arakan dalam upacara haul habib abu bakar bin Muhammad assegaf. Meski demikian, penetrasi tersebut hanya sampai pada model akulturasi overt culture, yaitu suatu bagian kebudayaan yang mudah berubah dan terpengaruh oleh unsur-unsur kebudayaan asing, yang dalam hal ini adalah keberadaan lontong cap go meh dan pertunjukan wayang kulit.

Dengan demikian, proses penetrasi pendidikan islam pada budaya dan agama masyarakat desa Pulopancikan Gresik adalah bersifat akulturatif. Menurut Koentjaraningrat, akulturasi adalah proses perpaduan antara dua kebudayaan atau lebih sehingga melahirkan bentuk kebudayaan baru, tetapi unsur-unsur penting dari masing-masing kebudayaan (baik kebudayaan lama maupun kebudayaan baru) masih bertahan. Akulturasi ini terjadi bila

\footnotetext{
${ }^{9}$ Ibid, 197-199.

${ }^{10}$ Koentjaraningrat. Pengantar Ilmu Antropologi. (Jakarta; PT. Rineka Cipta, (1990). 248.
} 
suatu kelompok manusia dengan suatu kebudayaan tertentu dihadapkan dengan unsur-unsur dari suatu kebudayaan asing, sehingga unsur-unsur kebudayaan asing itu lambat laun diterima dan diolah ke dalam kebudayaan sendiri tanpa menyebabkan hilangnya kepribadian kebudayaan itu sendiri. ${ }^{11}$

Model akulturasi yang ada di desa Pulopancikan Gresik terbukti dengan keberadaan sejumlah simbol budaya lokal yang masuk pada budaya masyarakat seperti: lontong cap go meh, dan pertunjukan wayang kulit dalam perayaan tahun baru imlek, serta arak-arakan dalam upacara haul Habib Abu Bakar bin Muhammad Assegaf. Meski demikian, penetrasi tersebut hanya sampai pada model akulturasi overt culture, yaitu suatu bagian kebudayaan yang mudah berubah dan terpengaruh oleh unsur-unsur kebudayaan asing, yang dalam hal ini adalah keberadaan lontong cap go meh dan pertunjukan wayang kulit. Hal ini berarti mempertegas penelitian sebelumnya yang berkaitan dengan hubungan budaya dengan agama yang dilakukan Mukti Ali (1980), ${ }^{12}$ Mitsuo Nakamura (1983), ${ }^{13}$ Hefner (1985), Woodward (1989), Prasetyo (1993), Headley (1997), Budiwanti (2000), ${ }^{14}$ Mulkhan (2000), Muhaimin (2001), Radam (2001), Bartholomew (2001), dan Masdar Hilmy (2001).

Di sisi lain, temuan ini berbeda dengan penelitian sebelumnya dalam kaitannya dengan corak interaksi masyarakat multikultur yang dilakukan oleh Muhammad Arif (2014), ${ }^{15}$ Anita Sugianta dkk. (2014), Mahruddin (2013), dan Sehat Ihsan Shadiqin (2011). Jika Muhammad Arif menyimpulkan bahwa interaksi masyarakat multikultur dilakukan melalui proses akulturasi dan asimilasi secara sekaligus, maka Anita Sugianta dkk., Mahruddin dan Sehat Ihsan Shadiqin menyimpulkan bahwa interaksi masyarakat multikultur dilakukan melalui proses sinkretik (asimilasi). Kedua peta kesimpulan ini berbeda dengan hasil temuan penelitian ini yang menyimpulkan bahwa interaksi masyarakat multikultur dilakukan melalui proses akulturasi. Dari proses penetrasi pendidikan agama islam pada agama dan budaya masyarakat yang bersifat akulturatif tersebut menghasilkan model multikulturalisme akomodatif-otonomis. Model ini dalam rumusan Bikhu Parekh belumlah ada. Sebab Parekh memetakan lima model

\footnotetext{
${ }^{11}$ Ibid.

${ }^{12}$ A. Mukti Ali. (1980). "The Evolution of Islam In Indonesia”. Jurnal: Volume 7 Nomor 4. Cultures

13 Mitsuo Nakamura. Bulan Sabit Muncul dari Balik Pohon Beringin. (Yogyakarta; Gajah Mada University Press, 1983).

14 Erni Budiwanti. Islam Sasak; Islam Wetu Lima Versus Islam Wetu Telu. (Yogyakarta; LKiS, 2000).

15 Muhammad Arif. "Model Kerukunan Sosial Pada Masyarakat Multikultural Cina Benteng; Kajian Historis Dan Sosiologis." Jurnal: Volume 1 Nomor 1. Sosio Didaktika. (Mei), 2014. 56.
} 
multikulturalisme yang berkembang di dunia, yaitu: multikulturalisme isolasionis, akomodatif, otonomis, kritikal atau interaktif, dan cosmopolitan. ${ }^{16}$

Dari kelima model tersebut tidak ada yang menjelaskan gambaran fakta multikultural yang berkembang di desa Pulopancikan Gresik. Sebab model multikulturalisme yang berkembang adalah realitas multikulturalisme dimana kelompok dominan membuat penyesuaian dan akomodasi bagi kebutuhan kultural kaum minoritas. Namun di sisi lain kelompok minoritas berupaya mewujudkan kesetaraan dengan budaya dominan mengharapkan kehidupan otonom dalam kerangka politik yang secara kolektif dapat diterima. Hal ini terbukti dari dengan keberadaan masyarakat etnis Arab yang berusaha mewujudkan kesetaraan (equality) dengan budaya masyarakat lokal yang dominan serta berharap memperoleh kehidupan otonom dalam kerangka politik yang secara kolektif dapat diterima meskipun masyarakat etnis lokal telah berupaya membuat penyesuaian dan akomodasi-akomodasi bagi kebutuhan kultural masyarakat etnis Arab yang minoritas. Meski demikian, kultur masyarakat etnis lokal yang dominan maupun kultur masyarakat etnis Arab yang minoritas dapat saling hidup berdampingan.

Gambaran realitas multikultural di atas di satu sisi merepresentasikan model multikultural akomodatif dan di satu sisi merepresentasikan model multikultural isolasionis. Meski berbeda, penulis tidak hendak membuat istilah model baru, sebab pada masing-masing bagian dari model multikultural yang berkembang di desa Pulopancikan Gresik telah merepresentasikan dua model multikultural Bikhu Parekh, yaitu: akomoadatif dan isolasionis. Oleh karena itu, penulis berinisatif menggabungkan kedua istilah tersebut menjadi model multikulturalisme akomodatif-isolasionis. Realitas model multikulturalisme ini dalam hemat penulis bukanlah model multikultural yang ideal. Sebab dalam masyarakat multikultur yang bermodel seperti ini, sesungguhnya masih terkandung bibit-bibit dominasi yang pada akhirnya tidak akan membawa pada keadilan sosial bagi kemaslahatan bersama. Sebab kelompok minoritas lebih memilih memisahkan diri dari kelompok dominan untuk menghindari ketidakadilan sosial. Hemat penulis model multikultural yang ideal adalah multikultural kosmopolitan, yaitu model multikulturalisme yang berusaha menghapuskan batas-batas kultural sama sekali untuk menciptakan sebuah masyarakat di mana setiap individu tidak lagi terikat kepada budaya tertentu. Sebaliknya, multikulturalisme kosmopolitan berusaha secara bebas terlibat dalam

16 Kenneth Thomson, ed. Media and Cultural Regulation. (London: Sage Publications, 1997), 183-185. 
eksperimen-eksperimen interkultural dan sekaligus mengembangkan kehidupan kultural masing-masing ${ }^{17}$

\section{PENUTUP}

Berdasarkan kajian yang telah dideskripsikan sebelumnya, maka dapat dinarasikan kesimpulannya bahwa proses pendidikan islam pada budaya dan agama masyarakat di Desa Pulopancikan berjalan bersifat akulturatif dengan corak overt culture. Dalam prosesnya penetrasi yang bersifat akulturatif ini dijalankan melalui beberapa unsur budaya masyarakat yang meliputi: sistem religi dan upacara keagamaan, sistem kekerabatan dan organisasi sosial, sistem teknologi dan sistem bahasa. Selain melalui unsur budaya masyarakat, penetrasi akulturatif juga dijalankan melalui sistem agama masyarakat yang meliputi: haddad-an, majelis rawhah, haul Habib Abu Bakar bin Muhammad Assegaf, perayaan tahun baru imlek, dan sembahyang rebutan.

\section{DAFTAR PUSTAKA}

\section{Buku}

Abdul Munir Mulkhan, 2000, Islam Murni Pada Masyarakat Petani. Yogyakarta; Bentang Budaya.

Erni Budiwanti. 2000, Islam Sasak; Islam Wetu Lima Versus Islam Wetu Telu. Yogyakarta; LKiS.

John Ryan Bartholomew. 2011, Alif Lam Mim; Kearifan Masyarakat Sasak. Yogyakarta; Tiara Wacana.

Kenneth Thomson, ed. 1997, Media and Cultural Regulation. (London: Sage Publications.

Koentjaraningrat. 1990, Pengantar Ilmu Antropologi. Jakarta; PT. Rineka Cipta.Mitsuo

Nakamura. 1983, Bulan Sabit Muncul dari Balik Pohon Beringin. Yogyakarta; Gajah Mada University Press.

Richard West \& Lynn H. Turner. 2007, Introducing Communication Theory: Analysis and Aplication. New York: Mc Graw-Hill Higher Education.

\section{Jurnal}

A. Mukti Ali. "The Evolution of Islam In Indonesia". Jurnal: Volume 7 Nomor 4. Cultures. 1980.

\footnotetext{
${ }^{17}$ Ibid.
} 
Muhammad Arif. "Model Kerukunan Sosial Pada Masyarakat Multikultural Cina Benteng; Kajian Historis Dan Sosiologis." Jurnal: Volume 1 Nomor 1. Sosio Didaktika. (Mei), 2014.

Stephen Headly, The Islamization of Central Java; The Role of Muslim Lineage in Kalioso. Jurnal: Volume 3 Nomor 2. Islamika, 1997. 
PADA BUDAYA DAN AGAMA MASYARAKAT (A. Thoyib Mas'udi) 